Paling et al., Afr., J. Infect. Dis. (2018) 12(S): 44-48

https://doi.org/10.2101/Ajid.v12i1S.5

\title{
ACANTHAMOEBA SP.S-11 PHAGOCYTOTIC ACTIVITY ON MYCOBACTERIUM LEPRAE IN DIFFERENT NUTRIENT CONDITIONS
}

\author{
Sepling Paling ${ }^{1 *}$, Ratna Wahyuni ${ }^{2}$, Ni’ matuzahroh ${ }^{1}$, Dwi Winarni ${ }^{1}$, Iswahyudi ${ }^{2}$, Linda Astari $^{3}$, Dinar \\ Adriaty $^{2}$, Indropo Agusni ${ }^{2,3}$, Shinzo Izumi ${ }^{2}$
}

${ }^{1}$ Department of Biology, Faculty of Science and Technology, Universitas Airlangga, Surabaya 60115, Indonesia; ${ }^{2}$ Leprosy Study Group, Institute of Tropical Disease, Universitas Airlangga, Surabaya 60115, Indonesia; ${ }^{3}$ Department of Dermatology and Venereology, Faculty of Medicine, Universitas Airlangga, Surabaya 60286, Indonesia.

*Corresponding Author's E-mail: seplinpalin@gmail.com

\begin{tabular}{|l|}
\hline \multicolumn{1}{|c|}{ Article History } \\
Received: March. 13, 2017 \\
Revised Received: Oct. 22, 2017 \\
Accepted: Oct. 24, 2017 \\
Published Online: March. 07, 2018 \\
\hline
\end{tabular}

\section{Abstract}

Background: Mycobacterium leprae (M. leprae) is a pathogenic bacterium that causes leprosy. The presence of M. leprae in the environment is supported by microorganisms that act as the new host for M. leprae. Acanthamoeba's potential to be a host of M. leprae in the environment. Acanthamoeba sp. is Free Living Amoeba (FLA) that classified as holozoic, saprophytic, and saprozoic. The existence of nutrients in the environment influence Acanthamoeba ability to phagocytosis or pinocytosis. This study is aimed to determine Acanthamoeba sp.S-11 phagocytic activity to Mycobacterium leprae (M. leprae) which cultured in non-nutrient media and riched-nutrient media.

Materials and Methods: This research conducted by culturing Acanthamoeba sp.S-11 and M. leprae on different nutrient media conditions. M. leprae intracellular DNA were isolated and amplified by $M$. leprae specific primers through Real Time PCR (Q-PCR).

Result: The results showed that Acanthamoeba co-cultured on non-nutrient media were more active to phagocyte M. leprae than on rich-nutrient media.

Conclusion: The use of non-nutrient media is recommended to optimize Acanthamoeba sp. phagocytic activity to $M$. leprae.

Keywords: Acanthamoeba sp., Mycbacterium leprae, Nutrient, Phagocytosis, Real Time PCR

\section{Introduction}

Mycobacterium leprae (M. leprae) is a pathogenic bacterium to humans and causes leprosy. Leprosy is one of the tropical diseases in Indonesia that causes permanent disability in the sufferer if treated late. Leprosy in Indonesia ranks third after Brazil and India in 2014. Leprosy prevalence rate has decreased, but new cases of leprosy continue to emerge even though the World Health Organization (WHO) Multidrug Therapy (MDT) program has been implemented (Ministry of Health of the Republic of Indonesia, 2013).

The emergence of leprosy new cases suspected on environmental factors that play a role in the leprosy transmission, especially in leprosy endemic areas. The big question is how the bacteria Mycobacterium leprae (M. leprae) can survive in the environment. While as known, M. leprae is a bacterium which transmitted through direct contact with the patient and can only live in the cell (intracellular obligate). Based on this, it is possible that M. leprae survives in the environment with the support of microorganisms as a new host for M. leprae.

Some research results reveal Acanthamoeba sp. is the most likely candidate to host M. leprae in the environment (Lahiri and Krahenbuhl, 2008; Agusni et al., 2009; Turankar et al., 2012; Wheat et al., 2014 ). Acanthamoeba sp. is a Free Living Amoeba (FLA) which is holozoic, saprophyte, and saprozoic as well as live freely in the environment. Acanthamoeba is Free Living Amoeba (FLA) which live freely in various environments (Khan, 2015) either on the ground (Sawyer, 1989; Tsvetkova et al., 2004; Lorenzo-Morales et al., 2005), various water environments (such as freshwater, 
seawater, soft lens cleaning water, and textile industry wastewater), dialysis units, coolers, artificial media (MarcianoCabral et al., 2000; Maghsood et al., 2005; Astorga et al., 2011; Wink et al., 2011; Siddiqui and Khan 2012; Trabelsi et al., 2012; Geisen et al., 2014; Mahmoudi et al., 2015; Thammaratana et al., 2016), and on air conditioning (AC) (Ithoi et al., 2011; Tanveer et al., 2013).

Acanthamoeba acts as a reservoir for several pathogenic bacteria that are resistant to the phagocytosis mechanism such as Mycobacterium leprae, Mycobacterium avium, Mycobacterium abscessus, Mycobacterium fortuitum, Mycobacterium ulcerans, Arcobacter butzleri, etc. (Gryseels et al., 2012; Medina et al., 2014; Drancourt, 2014; Wheat et al., 2014; Behera et al., 2016)

The nutrients existence in the environment affect Acanthamoeba ability to perform phagocytosis or pinocytosis. Acanthamoeba's ability to perform phagocytosis related to its life cycle. The active phase of Acanthamoeba is the tropozoite form. In this phase, Acanthamoeba is active to perform various physiological activities such as phagocytosis and digest various phagocytosed nutrients sources. While the Acanthamoeba silent phase is the cyst form. Phase of tropozoites and cysts according to Paling et al., 2016 influenced by the nutrients presence and incubation time.

This research observed Acanthamoeba Sp.S-11 phagocytic activity to co-cultured M. leprae cells on Page's Modified Neff' Amoeba Saline (PAS) media and Peptone Extract Yeast Glucose (PYG) media with varying incubation time. PAS media is a buffer media that contains no nutrients. While PYG media is the rich nutrients media.

\section{Materials and Methods}

This study was conducted at the Leprosy Study Group Laboratory, Institute of Tropical Disease (ITD) Airlangga University Surabaya. Isolat Acanthamoeba sp.S-11 and isolat Mycobacterium leprae used are the collection of ITD Leprosy Laboratory Airlangga University Surabaya.

Investigations were conducted using factorial experimental design with two replications. Before used Mycobacterium leprae (M. leprae) suspended with PAS and the cell count calculated by Zhiel Neelsen (ZN) staining and observed microscopically. Cell count is calculated based on the Breed method (Waluyo, 2010). Isolate Acanthamoeba sp.S11 dari $-70^{\circ} \mathrm{C}$ and cultured in $10 \mathrm{~mL}$ of PYG media in the $12 \mathrm{~mL}$ flask. After incubation for 3 days, Acanthamoeba sp.S-11 sub cultured as much $50 \mu \mathrm{L} / 8 \mathrm{~mL}$ media ATCC $712 \mathrm{PYG}$ (Peptone, Yeast extract, Distilled water, $0,4 \mathrm{M} \mathrm{MgSO}_{4}$. $7 \mathrm{H}_{2} \mathrm{O}$, $0,05 \mathrm{M} \mathrm{CaCl}_{2}, 0,1$ Sodium citrate. $2 \mathrm{H}_{2} \mathrm{O}, 0,005 \mathrm{M} \mathrm{Fe}\left(\mathrm{NH}_{4}\right)_{2}\left(\mathrm{SO}_{4}\right)_{2}$. $6 \mathrm{H}_{2} \mathrm{O}, 0,25 \mathrm{M} \mathrm{Na}_{2} \mathrm{HPO}_{4}$. $7 \mathrm{H}_{2} \mathrm{O}, 0,25 \mathrm{M} \mathrm{KH}_{2} \mathrm{PO}_{4}, 2$ $\mathrm{M}$ glucose) in $12 \mathrm{~mL}$ flask and incubated for 2 days. Initial and final number of subculture incubation calculated using hemocytometer which observed microscopically with 200X magnification.

$4 \times 10^{4}$ cells $/ \mu \mathrm{L}$ Mycobacterium leprae and $2 \times 10^{3}$ cells $/ \mu \mathrm{L}$ Acanthamoeba $\mathrm{sp} . \mathrm{S}-11$ co-cultured each in $1 \mathrm{~mL}$ of media PAS ( $\mathrm{NaCl}, \mathrm{MgSO}_{4} .7 \mathrm{H}_{2} \mathrm{O}, \mathrm{Na}_{2} \mathrm{HPO}_{4}, \mathrm{KH}_{2} \mathrm{PO}_{4}, \mathrm{CaCl}_{2} .2 \mathrm{H}_{2} \mathrm{O}$, Aquades) and PYG, then incubated for 0, 7, 14, 21, and 28 days at temperature $30^{\circ} \mathrm{C}$. Co-culture centrifuged at low speed $5000 \mathrm{~g}$ for 10 minutes. After that, the supernatant and pellet formed are separated. The pellet is suspended in 10x PAS volume, then spread made on the object through Ziehl Neelsen (ZN) staining by fast fixation of fire, then put solution of carbol fuchsin $0,3 \%$ to cover the entire preparation surface. The next step is the preparation incubated for 30 minutes. Then the preparations are rinsed in succession with running water and alcoholic acid ( $\mathrm{HCl} 3 \%$ in alcohol $70 \%$ ) until the red fuchsin disappears. The preparation rinsed with running water and then stained with methylene blue $0,3 \%$ until covering the entire surface for 1-2 minutes. Finally, the preparation rinsed with running water and kept to dry. Observations were recorded using 1000x magnification microscope.

Acanthamoeba sp.S-11 phagocytosis activity confirmed with Real Time PCR (qPCR) check by observing the amount of copy DNA M. leprae concentration. The first step is to isolate DNA M. leprae as template for qPCR. DNA $M$. leprae were isolated using Qiagen miniprep kit which is based on its manual's instructions. Once DNA obtained, then performed detection of DNA M. leprae by using qPCR (Amersham Biosystem 7300). The main component needed in detecting $M$. leprae DNA using qPCR are a pair of specific primers M. leprae, the primary forward Lp33F (5'AGGTGTCGGCGTGGTCAAT-3'), and primary reverse Lp33R (5'-AATGGTGCAAGGGATAACATCAG-3'), and require SyBrGreen Reagent. The detection performed on the operational standard of the qPCR user manual. The standard concentrated $M$. leprae series is included in each reaction for the quantity results consistency. The standard used are 100 $\mathrm{pg} / \mu \mathrm{l}, 10 \mathrm{pg} / \mu \mathrm{l}, 1 \mathrm{pg} / \mu \mathrm{l}, 0,1 \mathrm{pg} / \mu \mathrm{l}$, dan $0,01 \mathrm{pg} / \mu \mathrm{l}$. 


\section{Results}

Observation of Acanthamoeba sp.S-11 phagocytosis activity to M. leprae shown by the following figure:
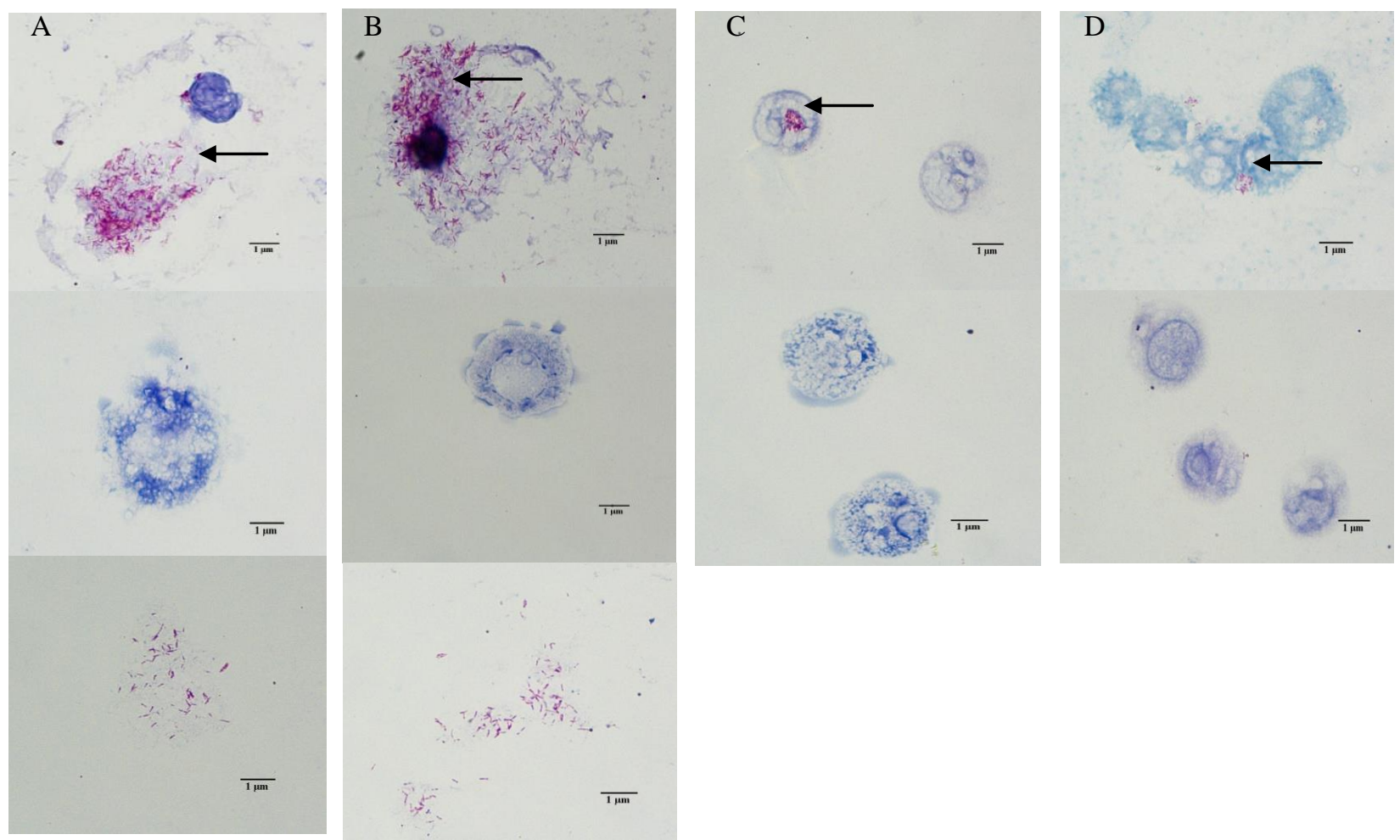

Figure 1: Acanthamoeba sp.S-11 phagocytosis activity to M. leprae. The black arrow shows M. Leprae cells that successfully phagocytosed by Acanthamoeba sp.S-11. A - B : Co-Culture on PAS media, C - D : Co-Culture on PAS media PYG, E - F : Acanthamoeba sp.S-11 control on PAS media, G - H : Acanthamoeba sp.S-11 control on PAS media PYG, I : M. leprae control on PAS media, J : M. leprae control on PAS media. ZN staining.

Confirmation of Acanthamoeba sp.S-11 phagocytosis activity, The real time PCR (qPCR) examination was performed. The results of qPCR examination can be seen in the following figure:

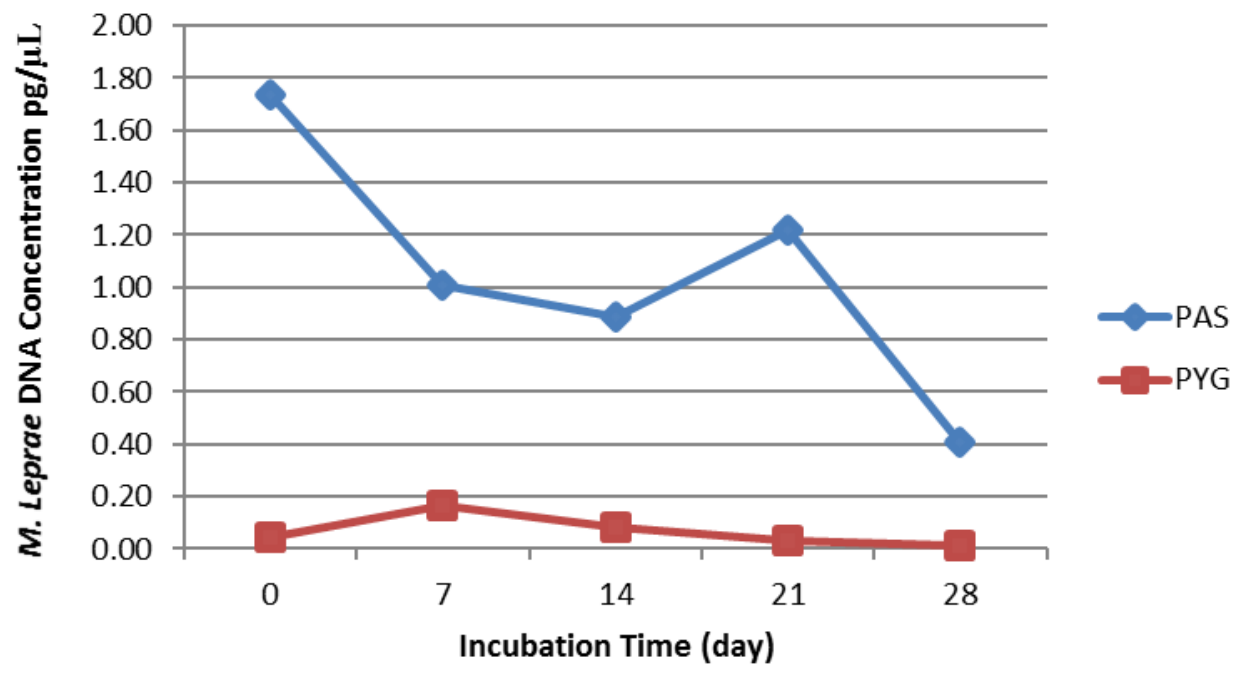

Figure 2: Concentration of M. leprae Intracellular DNA copy after Real Time PCR examination. 


\section{Discussion}

Based on figure 1, Acanthamoeba sp.S-11 phagocytosis activity to M. leprae that co-cultured on PAS media is much more effective than PYG media. Because PAS media used as co-culture media is a non-nutrient media thus forcing Acanthamoeba sp. S-11 to phagocytosis to M. leprae cells. Acanthamoeba sp.S-11 suppose that M. leprae as the nutrients source used as the energy source to perform its activities. Unlike PYG media that used as co-culture media showed Acanthamoeba sp.S-11 was not able to phagocytosis optimally to M. leprae cells around. Acanthamoeba sp. The S-11 prefers to pinocytosis to the nutrients contained in the PYG media. This supported by the qPCR results that shows the amount of M. leprae intraseluler copy DNA concentration that co-cultured on PAS media are higher than co-culture on PYG media.

The result of qPCR in figure 2 shows the growth pattern of M. leprae co-culture on PAS media and co-culture on PYG media. M. leprae cell grows on the 7th day of co-culture on PYG media and grows on the 21st day of co-culture on PAS media. Thus it can be said that $M$. leprae cells have the ability to multiply in Acanthamoeba sp. S-11 cells. However, further research on the mechanism of growth of cultured M. leprae cells with Acanthamoeba sp.S-11 is required.

Pinocytosis is the process of nutrients absorption in the form of small molecules or small particles such as amino acids, ions, and glucose through Acanthamoeba cell membranes by cytoplasmic invagination that curved inward to form the pinocytosis bubble called pinosomes. Pinositosis performed by Acanthamoeba sp.S-11 caused by the nature of nutrients molecules contained in the PYG media which always moves to occupy the entire space in the media, so Acanthamoeba Sp.S-11 does not need to perform an active movement to get the nutrients since directly those nutrient molecules will be attached themselves to Acanthamoeba sp.S-11 cell membrane, due to the presence of protein receptors and ions around and inside the cell resulting in invagination mechanism in the Acanthamoeba Sp.S-11 cell membrane until the molecules absorbed in Acanthamoeba sp.S-11 cytoplasm. In addition, Acanthamoeba prefers to pinocytosis since the small molecules such as amino acids, glucose, and ions contained in PYG media are the simple-form molecule making it easily absorbed and digested by Acanthamoeba sp.S-11 cells compared to solid particles with still very complex shape, such as bacteria, algae, bits of plants and animals that have died, or other solids particles either detrimental or beneficial to the Acanthamoeba cells thus requiring a certain mechanism to digest the solids particles into simpler molecular components. Digestive mechanism or so-called degranulation done through a fusion of the phagosome and enzyme produced by lysosome. The lysosome is a membrane organelle that originates from the Golgi body and contains acid and hydrolytic enzymes (Ruppert et al., 2004). PYG media is an artificial medium that can support the growth of Acanthamoeba (Heredero-Bermejo et al., 2012, Peretz et al., 2015) So when PYG media used as co-culture medium, Acanthamoeba cells will multiply rapidly.

\section{Conclusion}

The nutrients presence in the environment can inhibit Acanthamoeba sp.S-11 phagocytosis activity to M. Leprae. Meanwhile, the absence of nutrients in the environment will increase the Acanthamoeba sp.S-11 phagocytosis activity to M. Leprae.

Conflict of Interest: The authors state that there are no conflicts of interest regarding the publication of this paper.

\section{References}

1. Agusni Indropo, Prakoeswa Cita Rosita Sigit, Adriaty Dinar, dan Basuki S. (2009). Studi Transmisi di Daerah Endemis Kusta Lamongan Jawa Timur : Deteksi Mycobacterium leprae dan Identifikasi Protozoa Sebagai Sumber Penularan Non-Manusia pada Lingkungan. Universitas Airlangga Surabaya.

2. Astorga B, Lorenzo-Morales J, Martin-Navarro CM, Alarcon V, Moreno J, Gonzalez AC, Navarrete E, Pinero JE, Valladares B. (2011). Acanthamoeba Belonging to T3, T4, and T11: Genotypes Isolated from Air-Conditioning Units in Santiago, Chile. J. Eukaryot Microbiol 58:542-544. DOI: 10.1111/j.1550-7408.2011.00584.x.

3. Behera HS, Satpathy G. (2016). Characterisation and Expression Analysis of Trophozite and Cyst Proteins of Acanthamoeba spp. Isolated from Acanthamoeba keratitis. Molecular and Biochem Parasitol 205: 29-34.

4. Drancourt M. (2014). Looking in Amoebae as a Source of Mycobacterium. Microbial Pathogenesis 77: 119-124.

5. Geisen S, Fiore-Donno AM, Walochnik J, Bonkowski M. (2014). Acanthamoeba Everywhere: High Diversity of Acanthamoeba in Soils, Parasitol Res (Springer) 113:3151-3158, DOI 10.1007/s00436-014-3976-8.

6. Gryseels S, Amissah D, Durnez L, Vandelannoote K, Leirs H, Jonckheere JD, Silva MT, Portaels F, Ablordey A, Eddyani M. (2012). Amoebae as Potential Environmental Hosts for Mycobacterium ulcerans and Other Mycobacteria, but Doubtful Actors in Buruli Ulcer Epidemiology, Plos Negl Trop Dis 6(8): e1764. doi:10.1371/journal.pntd.0001764. 
7. Heredero-Bermejo, Martin CSJ, Carranza JS, Copa-Patino JL, Pérez-Serrano J. (2012). Acanthamoeba castellanii: in vitro UAH-T17c3 trophozoite growth study in different culture media I. J. Parasitol Res. 2012. 110:2563-2567 DOI 10.1007/s00436-011-2761-1.

8. Ithoi I, Ahmad AF, Nissapatorn V, Lau YL, Mahmud R, Mak JW. (2011). Detection of Naegleria Species in Environmental Samples from Peninsular Malaysia. Plos One 6 (9): e24327.

9. Khan NA. (2015). Acanthamoeba, Biology and Pathogenesis. Second Edition Caister Academic Press, Norfolk, Uk.

10. Lahiri, R and Krahenbhul JL. (2008). The Role Of Free-Living Pathogenic Amoeba In The Transmission of Leprosy: A Proof Of Principle. Leprosy Rev. 79: 401-409.

11. Lorenzo-Morales J, Ortiga-Rivas A, Martinez E, Foronda P, Valladares B. (2005). Isolation and Identification of Pathogenesis Acanthamoeba Strains in Tenerife, Canary Island, Spain from Water Source. Parasitol Res. 95:273277.

12. Ministry of Health of the Republic of Indonesia (2013). Centre of Data and Health Information.

13. Medina G, Flores-Martin S, Fonseca B, Otth C, Fernandez H. (2014). Mechanism Associated with Phagocytosis of Acrobacter butzleri by Acanthamoeba castellanii. Parasitol. Res. 113:1933-1942. DOI:10.1007/s00436-014-38428 .

14. Maghsood AH, Sissons J, Rezaian M, Nolder D, Warhurst D, Khan NA. (2005). Acanthamoeba Genotype T4 from the UK and Iran and Isolation of the T2 Genotype from Clinical Isolates. J. Med Microbiol 54 (Pt 8):755-759.

15. Mahmoudi MR, Rahmati B, Seyedpour SH, Karanis P. (2015). Occurrence and Molecular Characterization of Free-Living Amoeba Species (Acanthamoeba, Hartmannella, and Saccamoeba limax) in Various Surface Water Resources of Iran. Parasitol. Res. 114(12):4669-4674.

16. Marciano-Cabral F, Puffenbarger R, Cabral GA. (2000). The Increasing Importance of Acanthamoeba Infections. J. Eukaryot Microbiol 47(1):29-36.

17. Paling Sepling, Ni'matuzahroh, Winarni Dwi, Khaleyla Firaz, Wahyuni Ratna (2016). Adaptasi Morfologi Acanthamoeba Sp.S-11 Terhadap Variasi Konsentrasi Peptone-Yeast Extract-Glucose (PYG) dan Variasi Waktu Inkubasi. Semnas Biodiversitas IV Universitas Airlangga Surabaya.

18. Peretz A, Geffen Y, Socea SD, Pastukh N, Graff S. (2015). Compariosin of Fluorescence Microscopy and Different Growth Media Culture Methods for Acanthamoeba keratitis Diagnosis. Am J Trop Med Hyg, 93: 316318.

19. Ruppert EE, Fox RS, and Barnes RD. (2004). Invertebrate Zoology : A Functional Evolutionary Approch $7^{\text {th }}$ ed. Brooks/Cole, Thomson Learning Inc. USA.

20. Sawyer TK. (1989). Free-Living Pathogenic and Nonpathogenic Amoebae in Maryland Soils. Appl. Environ. Microbiol. 55: 1074-1077.

21. Siddiqui R, Khan NA. (2012). War of the Microbial Worlds: Who is the Beneficiary in Acanthamoeba-Bacterial interactions? Exp. Parasitol. 130: 311-313.

22. Tanveer T, Hameed A, Muazzam AG, Jung SY, Gul A, Matin A. (2013). Isolation and Molecular Characterization of Potentially Pathogenic Acanthamoeba Genotypes from Diverse Water Resources Including Household Drinking Water from Khyber Pakhtunkhwa, Pakistan. Parasitol. Res. 112: 2925-2932.

23. Thammaratana T, Laummaunwai P, Boonmars T. (2016). Isolation and Identification of Acanthamoeba Species from Natural Water Sources in the Northeastern Part of Thailand. Parasitol. Res. 115: 1705-1709.

24. Trabelsi H, Dendana F, Sellami H, Cheikhrouhou F, Neji S, Makni F, Ayadi A. (2012). Pathogenic Free-Living Amoeba: Epidemiology and Clinical Review. Pathol Biol 60: 399-405. DOI: 10.1016/j.patbio.2012.03.002.

25. Tsvetkova N, Schild M, Panaiotov S, Kurdova-Mintcheva R, Gottstein B, Walochnik J, Aspo H, Siles M, Muller LN. (2004). The Identification of Free-Living Environmental Isolates of Amoebae from Bulgaria. Parasitol. Res. 92: 4-5-413.

26. Turankar RP, Lavania M, Singh M. Sai KSRS, Jadhav RS. (2012). Dynamic of Mycobacterium leprae Transmission in Enviromental Context: Deciphering the Role of Environment as a Potential Reservoir., Inf, Gen \& Ev 12: 121-126.

27. Waluyo L. (2010). Teknik dan Metode Dasar Dalam Mikrobiologi, Malang : Universitas Muhammadiyah Malang.

28. Wheat WH, Casali AL, Thomas V, Spencer JS, Lahiri R, Williams DL, McDonnell, GE, Gonzalez-Juarrero, Brennan, PJ, and Jackson, M. (2014). Long-term Survival and Virulence of Mycobacterium leprae in Amoebal Cysts. Plos. 8: 1-14.

29. Wink MA, Caumo K, Rott MB. (2011). Prevalence of Acanthamoeba from Tap Water in Rio Grande do Sul, Brazil. Curr Microbiol 63:464-469. DOI: 10.1007/s00284-011-0003-5. 